\title{
Perhitungan Cost of Treatment pada Pasien Rawat Inap Penderita Stroke Peserta BPJS di RSUD dr. Mohamad Saleh Kota Probolinggo
}

\author{
The Calculation of Cost of Treatment of Hospitalized Stroke Patients as BPJS \\ Participants in RSUD dr. Mohamad Saleh Probolinggo City
}

\author{
Azizah Munawwarah ${ }^{1}$, Eri Witcahyo ${ }^{1}$, Sri Utami $^{1}$ \\ ${ }^{1}$ Bagian Administrasi dan Kebijakan Kesehatan, Fakultas Kesehatan Masyarakat, Universitas Jember
}

Korespondensi: Eri Witcahyo

E-mail: ewitcahyo@unej.ac.id

\begin{abstract}
Abstrak
Stroke merupakan salah satu penyakit katastropik yang menjadi penyebab kematian paling banyak di Indonesia. Kota Probolinggo merupakan kota dengan prevalensi stroke tertinggi kedua di Jawa Timur. Prevalensi dan kematian akibat stroke ini terus meningkat di RSUD dr. Mohamad Saleh Kota Probolinggo. Stroke merupakan penyakit berbiaya tinggi dan secara komplikasi dapat membahayakan jiwa, sehingga dibutuhkan pengelolaan pembiayaan yang tepat untuk menjamin efektifitas dan efisiensi pelayanan kesehatan penyakit ini. Oleh karena itu, perlu dilakukan studi mengenai cost of treatment yang mengukur biaya perawatan per episode layanan dari stroke. Tujuan penelitian ini untuk mengetahui gambaran perhitungan cost of treatment pada penderita stroke peserta BPJS di RSUD dr. Mohamad Saleh Kota Probolinggo. Studi ini merupakan studi evaluasi ekonomi parsial, dimana bertujuan untuk mendeskripsikan suatu objek biaya tanpa ada perbandingan terhadap intervensi lain yang dilakukan di RSUD dr. Mohamad Saleh Kota Probolinggo. Sampel penelitian adalah penderita stroke peserta BPJS di RSUD dr. Mohamad Saleh yang memenuhi kriteria inklusi dan eksklusi yaitu sebanyak 40 responden. Hasil penelitian menunjukkan ratarata biaya langsung sebesar Rp 8.278.584. Rata-rata indirect cost sebesar Rp 974.383. Sedangkan rerata biaya per satu episode layanan stroke sebesar Rp 9.252.967. Saran yang diberikan adalah meningkatkan pencatatan tindakan keperawatan yang baik serta dilengkapi dengan tindakan koreksi ulang. Perlu dilakukan monitoring dan evaluasi berkala terhadap billing sebagai bentuk pengendalian biaya.

Kata kunci: cost of treatment, pasien rawat inap, stroke.
\end{abstract}

\section{Abstract}

Stroke is one of the catastrophic diseases which is the most cause of death in Indonesia. Probolinggo is the second highest prevalence city of stroke in East Java. The prevalence and mortality of stroke have increased in RSUD dr. Mohamad Saleh Probolinggo. Stroke is a high-cost and life-threatening disease, so that the propitious financial management is needed to ensure the effectiveness and efficiency of this services. Therefore, it is necessary to do a study of cost of treatment that measures the cost of stroke treatment. The purpose of this study was to describe cost of treatment of stroke patients as BPJS participants in RSUD dr. Mohamad Saleh Probolinggo. This study was partial economic evaluation that aim to describe a cost of an object without comparing with other intervention. It was carried out at RSUD dr. Mohamad Saleh Probolinggo. Sample of this study were stroke patients as BPJS participants in RSUD dr. Mohamad Saleh Probolinggo of 2018 who fulfilled the inclusion and exclusion criteria which is consisted of 40 respondents. The results show that average of direct cost is IDR. 8,278,584. Average of indirect costs is IDR. 974,383. While average of cost of treatment is IDR. 9,252,967. The recommendation is to increase the good recording of nursing actions and do corrective actions. Implementing the monitoring and evaluation to carry out the cost containment.

Keywords: cost of treatment, hospitalized patient, stroke. 


\section{Pendahuluan}

Adanya suatu penyakit (baik penyakit menular maupun penyakit tidak menular) di suatu komunitas atau negara akan menimbulkan suatu beban penyakit (burden of disease). Hasil Riset Kesehatan Dasar (Riskesdas) tahun 2007 dan Survei Kesehatan Rumah Tangga (SKRT) tahun 1995 dan 2001 menunjukkan bahwa selama 12 tahun (1995-2007) Indonesia telah terjadi transisi epidemiologi. Hal ini menunjukkan bahwa kematian karena penyakit menular menurun, sedangkan kematian karena penyakit tidak menular terus meningkat (Kementerian Kesehatan Republik Indonesia, 2013).

Secara global, Penyakit Tidak Menular (PTM) yang menjadi penyebab kematian nomor satu setiap tahunnya adalah penyakit kardiovaskuler. Pada tahun 2008, diperkirakan sebanyak 9,4 juta kematian disebabkan oleh komplikasi hipertensi dan $51 \%$ diantaranya karena penyakit stroke (Kementerian Kesehatan Republik Indonesia, 2014a). Stroke merupakan salah satu penyakit katastropik yang membutuhkan biaya tinggi dan secara komplikasi dapat membahayakan jiwa (Kementerian Kesehatan Republik Indonesia, 2014b).

Berdasarkan hasil Riskesdas 2013 Jawa Timur, prevalensi stroke di Kota probolinggo berdasarkan diagnosis tenaga kesehatan adalah sebesar $8,4 \%$. Sedangkan berdasarkan diagnosis tenaga kesehatan dengan gejala prevalensinya sebesar 29,1\% (Laksmiarti et al., 2013). Selain itu, studi pendahuluan menunjukkan bahwa kasus stroke yang ditangani dan dirujuk ke RSUD dr. Mohamad Saleh Kota Probolinggo dari tahun 2014-2017 memiliki jumlah yang cukup tinggi. Jumlah kasus penyakit stroke tahun 2014 dan 2015 yakni sebanyak 453 dan 443 kasus. Pada tahun 2016 kasus stroke ini meningkat sebesar $11,9 \%$ dan terus mengalami peningkatan sebesar 24,6\% pada tahun 2017.

Tingginya prevalensi, angka rawat inap, morbiditas dan mortalitas memberikan dampak sosial ekonomi bagi penderita stroke (Hudayani, 2016). Dampak ini juga diperparah dengan besarnya biaya pengobatan penyakit stroke. Selain biaya pengobatan stroke yang cukup besar, adanya kecenderungan peningkatan biaya kesehatan yang terjadi di Indonesia akan menambah beban bagi penderita penyakit stroke (Chee et al. dalam Puspandari, 2015).

Untuk mengatasi beban biaya kesehatan di masyarakat, pada tahun 2004 dikeluarkan Undang-Undang No. 40 tentang Sistem Jaminan Sosial Nasional (SJSN). Peraturan ini mengamanatkan jaminan sosial wajib bagi seluruh penduduk termasuk Jaminan Kesehatan Nasional (JKN) yang diselenggarakan oleh Badan Penyelenggara Jaminan Sosial (BPJS). Kepesertaan JKN di RSUD dr. Mohamad Saleh terus mengalami peningkatan dari tahun ke tahun. Pada tahun 2014, jumlah peserta BPJS dari seluruh total pasien stroke adalah sebanyak $70 \%$. Kemudian pada tahun 2015 persentase peserta BPJS pada seluruh pasien stroke adalah sebesar 65\%. Persentase ini kemudian meningkat menjadi $71 \%$ pada tahun 2016 dan $72 \%$ pada tahun 2017.

Banyaknya peserta BPJS yang menderita penyakit stroke ini menyebabkan besarnya biaya JKN yang harus dikeluarkan untuk menangani stroke. Beban biaya JKN untuk penyakit stroke mengalami peningkatan dari tahun 2014-2016. Pada tahun 2014 beban biaya JKN untuk penyakit stroke mencapai nilai Rp 813.392.575.957,-. Nilai tersebut kemudian meningkat di tahun 2015 yakni menjadi Rp 1.131.104.070.060,- hingga pada tahun 2016 nilai ini mencapai Rp 1.171.127.754.410,- (Badan Penyelenggara Jaminan Sosial, 2017).

Berdasarkan uraian permasalahan yang telah dijabarkan di atas, serta melihat tingginya beban akibat keberadaan penyakit stroke maka perlu dilakukan studi mengenai cost of treatment atau biaya perawatan. Studi ini merupakan studi yang 
mengukur besarnya biaya per satu episode pelayanan stroke.

\section{Metode Penelitian}

Penelitian ini merupakan studi evaluasi ekonomi parsial. Penelitian ini bertujuan untuk mengetahui gambaran cost of treatment pada penderita stroke peserta BPJS di RSUD dr. Mohamad Saleh Kota Probolinggo. Studi ini merupakan perhitungan biaya dari perspektif pasien.

Penelitian ini dilakukan di RSUD dr. Mohamad Saleh Kota Probolinggo dari Bulan Agustus-Oktober 2018. Populasi penelitiannya adalah penderita stroke yang terdaftar di RSUD dr. Mohamad Saleh Kota Probolinggo sebagai peserta BPJS. Kriteria inklusi populasi pada penelitian ini adalah sebagai berikut:

a. Pasien stroke hemoragik dan iskemik (Kode diagnosa I60-I69 dan G45.9)

b. Pasien dengan data rekam medik dan pembiayaan yang lengkap

c. Pasien yang mengalami serangan stroke pertama

d. Pasien rawat inap kelas tiga

e. Pasien tahun 2018

f. Pasien peserta JKN

Sedangkan kriteria eksklusi pada penelitian ini adalah sebagai berikut:

a. Pasien stroke dengan komorbid penyakit yang tidak ada hubungannya dengan sistem vaskuler meliputi kanker, TBC, dan HIV/AIDS.

Sampel penelitian ini merupakan seluruh populasi penelitian yang ada pada saat dilaksanakan penelitian atau disebut dengan convenient sampling atau accidental sampling. Convenient sampling atau accidental sampling diartikan sebagai prosedur memilih sampel dari orang yang paling mudah dijumpai. Lebih lanjut Sugiyono (2015) menjelaskan bahwa accidental sampling merupakan pemilihan responden sebagai sampel berdasarkan kebetulan, yaitu secara kebetulan bertemu dengan peneliti dan dapat memenuhi kriteria sampel.

Sumber data dalam penelitian ini adalah data primer dan data sekunder. Data primer diperoleh melalui wawancara dengan kuesioner. Wawancara ini dilakukan secara exit poll kepada pasien/keluarga pasien, setelah pasien mendapatkan treatment. Sedangkan data sekunder didapat melalui catatan rekam medis pasien. Data yang diperoleh melalui penelitian selanjutnya perlu dibersihkan sehingga mampu diolah menjadi informasi yang digunakan untuk menjawab pertanyaan penelitian. Analisis data menggunakan analisis univariat.

Selain itu juga dilakukan perhitungan untuk mendapatkan direct cost dan indirect cost. Direct cost didapatkan dengan menghitung rata-rata dari seluruh komponen direct cost yang didapatkan dengan melihat data detailed billing pasien. Data billing adalah direct cost yang ditanggung oleh BPJS Kesehatan. direct cost) diidentifikasi dari biaya rawat jalan dan biaya rawat inap. Biaya rawat jalan terdiri dari biaya kunjungan fasilitas kesehatan tingkat pertama (FKTP) dan biaya transportasi FKTP. Sedangkan biaya rawat inap terdiri dari biaya perawatan rawat inap (IRD, Administrasi, Akomodasi/Kamar, Jasa Pelayanan Dokter, Lab, Radiologi, Tindakan Keperawatan, Farmasi, Visite, Jasa Keperawatan, dan gizi) dan biaya transportasi rawat inap.

Sementara itu, indirect cost didapatkan dengan rata-rata dari seluruh komponen indirect cost yang didapatkan melalui wawancara kepada pasien secara langsung. Indirect cost diidentifikasi dari pendapatan yang hilang akibat sakit dari pasien, pendapatan yang hilang dari pendamping pasien dan biaya lain-lain.

Setelah mendapatkan direct cost dan indirect cost, selanjutnya dilakukan penjumlahan untuk mendapatkan satu kesatuan cost of treatment. Perhitungan ini dilakukan selama pasien menjalani perawatan di rumah sakit. 


\section{Hasil}

\section{Direct Cost}

Tabel di bawah ini merupakan hasil analisis statistik deskriptif mengenai komponen direct cost penderita stroke peserta BPJS di RSUD dr. Mohamad Saleh Kota Probolinggo.

Tabel 1. Analisis Statistik Deskriptif Komponen Direct Cost

\begin{tabular}{llr}
\hline $\begin{array}{c}\text { Komponen Direct } \\
\text { Cost }\end{array}$ & \multicolumn{2}{c}{ Hasil } \\
\hline Biaya Rawat Jalan & & \\
\hline Rata-rata & $\mathrm{Rp}$ & 58.380 \\
Nilai minimum & $\mathrm{Rp}$ & 0 \\
Nilai maksimum & $\mathrm{Rp}$ & 1.752 .000 \\
\hline Biaya Rawat Inap & & \\
\hline Rata-rata & $\mathrm{Rp}$ & 8.227 .641 \\
Nilai minimum & $\mathrm{Rp}$ & 2.024 .179 \\
Nilai maksimum & $\mathrm{Rp}$ & 22.523 .079 \\
\hline
\end{tabular}

Berdasarkan Tabel 1 di atas, dapat diketahui bahwa rata-rata biaya rawat jalan yang dikeluarkan oleh responden adalah Rp58.380. Sedangkan rata-rata biaya rawat inap yang dikeluarkan oleh responden adalah Rp 8.220.204. Dari kedua komponen biaya langsung tersebut 98\% diantaranya adalah biaya rawat inap dan sekitar $2 \%$ diantaranya merupakan biaya rawat jalan. Dari kedua jenis biaya di atas, kemudian dijumlahkan sehingga menghasilkan biaya langsung.

Tabel 1. Analisis Statistik Deskriptif Direct

\begin{tabular}{lr}
\multicolumn{2}{c}{ Cost } \\
\hline \multicolumn{1}{c}{ Direct Cost } & Hasil \\
\hline Rata-rata & Rp8.286.021 \\
Nilai minimum & Rp2.074.179 \\
Nilai maksimum & Rp22.534.479 \\
\hline
\end{tabular}

Berdasarkan tabel 2 di atas diketahui bahwa rata-rata direct cost yang dikeluarkan oleh responden adalah $R p$ 8.278.584. Nilai minimum dari direct cost adalah $R p$ 2.024.179. Sedangkan nilai maksimum dari direct cost adalah $\mathrm{Rp}$ 22.534.479.

\section{Indirect cost}

Indirect cost diartikan sebagai biaya penunjang yang dikeluarkan pasien untuk mendapatkan perawatan dan pengobatan terhadap penyakit stroke dideritanya. Indirect cost ini dihitung dari pendapatan yang hilang dari pasien, pendapatan yang hilang dari pendamping pasien, biaya transportasi pasien, biaya makan dan minum, biaya kebutuhan higien. Tabel di bawah ini merupakan hasil analisis statistik deskriptif indirect cost penderita stroke peserta BPJS di RSUD dr. Mohamad Saleh Kota Probolinggo berdasarkan komponen.

\section{Tabel 3. Analisis Statistik Deskriptif}

Komponen Indirect cost (Indirect Cost)

\begin{tabular}{lcr}
\hline Komponen Indirect Cost & \multicolumn{2}{l}{ Hasil } \\
\hline \multicolumn{4}{l}{ Pendapatan pasien yang hilang } & \\
\hline Rata-rata & $\mathrm{Rp}$ & 22.750 \\
Nilai minimum & $\mathrm{Rp}$ & 0 \\
Nilai maksimum & $\mathrm{Rp}$ & 450.000 \\
\hline \multicolumn{4}{l}{ Pendapatan Pendamping yang Hilang } & \\
\hline Rata-rata & $\mathrm{Rp}$ & 0 \\
Nilai minimum & $\mathrm{Rp}$ & 0 \\
Nilai maksimum & $\mathrm{Rp}$ & 0 \\
\hline Biaya Lain-Lain & & \\
\hline Rata-rata & $\mathrm{Rp}$ & 967.400 \\
Nilai minimum & $\mathrm{Rp}$ & 392.800 \\
Nilai maksimum & $\mathrm{Rp}$ & 2.642 .000 \\
\hline
\end{tabular}

Berdasarkan tabel 3 di atas, diketahui bahwa rata-rata pendapatan pasien yang hilang sebesar Rp 22.750. Rata-rata pendapatan pendamping pasien yang hilang sebesar $\mathrm{Rp} 0$. Sedangkan ratarata biaya lain-lain yang dikeluarkan responden sebesar Rp 967.400. Hal ini menunjukkan bahwa komponen terbesar indirect cost adalah biaya 
lain-lain. Dari ketiga jenis biaya tersebut kemudian dijumlahkan hingga menghasilkan indirect cost.

Tabel 4. Analisis Statistik Deskriptif Indirect

\begin{tabular}{llr}
\multicolumn{3}{c}{ Cost } \\
\hline \multicolumn{1}{c}{$\begin{array}{c}\text { Indirect Cost } \\
\text { (Indirect cost) }\end{array}$} & & \multicolumn{1}{c}{ Hasil } \\
\hline Rata-rata & $\mathrm{Rp}$ & 998.128 \\
Nilai minimum & $\mathrm{Rp}$ & 392.800 \\
Nilai maksimum & $\mathrm{Rp}$ & 3.092 .000 \\
\hline
\end{tabular}

Berdasarkan tabel 4 di atas dapat diketahui bahwa rata-rata indirect cost yang dikeluarkan oleh responden adalah Rp 998.128. Sementara itu, nilai minimum dari indirect cost yang dikeluarkan responden adalah $\mathrm{Rp} 392.800$. Sedangkan nilai maksimum dari indirect cost adalah Rp 3.092.000.

\section{Cost of Treatment}

Cost of treatment diidentifikasi dari dua jenis biaya yaitu, direct cost dan indirect cost. Dari kedua jenis biaya tersebut kemudian dijumlahkan hingga menghasilkan suatu total biaya perawatan (cost of treatment) dalam satu periode sakit pada penderita stroke peserta BPJS di RSUD dr. Mohamad Saleh Kota Probolinggo. Berikut pada tabel 5 di bawah ini akan disajikan analisis statistik deskriptif mengenai biaya perawatan (cost of treatment) pada penderita stroke peserta BPJS di RSUD dr. Mohamad Saleh Kota Probolinggo.

Tabel 2. Distribusi Biaya Sakit (Cost of

\begin{tabular}{ccc}
\multicolumn{3}{c}{ treatment) } \\
\hline $\begin{array}{c}\text { Cost of treatment } \\
\text { (Biaya Sakit) }\end{array}$ & \multicolumn{2}{c}{ Hasil } \\
\hline Rata-rata & $\mathrm{Rp}$ & 9.260 .404 \\
Nilai minimum & $\mathrm{Rp}$ & 2.816 .979 \\
Nilai maksimum & $\mathrm{Rp}$ & 24.242 .679 \\
\hline
\end{tabular}

Berdasarkan tabel 5 di atas dapat diketahui bahwa rata-rata biaya sakit adalah $\mathrm{Rp}$ 9.260.404. Sementara itu, nilai minimum dari biaya sakit yang dikeluarkan responden adalah $\mathrm{Rp}$ 2.816.979. Sedangkan nilai maksimum dari biaya sakit (cost of treatment) adalah sebesar $\mathrm{Rp}$ 24.242.679. Biaya sakit atau cost of treatment di atas dapat dikelompokkan berdasarkan klasifikasi utama stroke dan berdasarkan ICD-10.

Tabel 3 Klasifikasi Biaya Sakit Stroke

\begin{tabular}{|c|c|c|}
\hline Klasifikasi Stroke & & Hasil \\
\hline \multicolumn{3}{|c|}{ Klasifikasi Utama Stroke } \\
\hline \multicolumn{3}{|l|}{ Stroke Iskemik } \\
\hline Rata-Rata & $\mathrm{Rp}$ & 8.458 .941 \\
\hline Nilai minimum & $\mathrm{Rp}$ & 2.816 .979 \\
\hline Nilai maksimum & $\mathrm{Rp}$ & 21.688 .944 \\
\hline \multicolumn{3}{|l|}{ Stroke Hemoragik } \\
\hline Rata-Rata & $\mathrm{Rp}$ & 12.220 .429 \\
\hline Nilai minimum & $\mathrm{Rp}$ & 6.759 .491 \\
\hline Nilai maksimum & $\mathrm{Rp}$ & 24.242 .679 \\
\hline \multicolumn{3}{|l|}{$T I A$} \\
\hline Rata-Rata & $\mathrm{Rp}$ & 3.686 .268 \\
\hline Nilai minimum & $\mathrm{Rp}$ & 3.548 .261 \\
\hline \multicolumn{3}{|l|}{ Klasifikasi ICD-10 } \\
\hline \multicolumn{3}{|l|}{ CVA Infarct } \\
\hline Rata-Rata & $\mathrm{Rp}$ & 7.866.288 \\
\hline Nilai minimum & $\mathrm{Rp}$ & 2.766 .979 \\
\hline Nilai maksimum & $\mathrm{Rp}$ & 17.018 .591 \\
\hline \multicolumn{3}{|c|}{ CVA infarct due to embolism } \\
\hline Rata-Rata & $\mathrm{Rp}$ & 13.176 .836 \\
\hline Nilai minimum & $\mathrm{Rp}$ & 7. 883.209 \\
\hline Nilai maksimum & $\mathrm{Rp}$ & 21.688 .944 \\
\hline \multicolumn{3}{|l|}{ ICH } \\
\hline Rata-Rata & $\mathrm{Rp}$ & 12.220 .429 \\
\hline Nilai minimum & $\mathrm{Rp}$ & 6.759 .491 \\
\hline Nilai maksimum & $\mathrm{Rp}$ & 24.242 .679 \\
\hline \multicolumn{3}{|l|}{ TIA } \\
\hline Rata-Rata & $\mathrm{Rp}$ & 3.686 .268 \\
\hline Nilai minimum & $\mathrm{Rp}$ & 3.548 .261 \\
\hline Nilai maksimum & $\mathrm{Rp}$ & 3.824 .274 \\
\hline
\end{tabular}


Berdasarkan tabel 6 di atas diketahui bahwa terdapat 2 jenis klasifikasi stroke yaitu klasifikasi utama dan berdasarkan ICD-10. Berdasarkan klasifikasi utama, terdapat 3 jenis stroke yaitu stroke iskemik, stroke hemoragik, dan TIA. Dari ketiga jenis stroke tersebut yang memiliki ratarata biaya sakit tertinggi adalah stroke hemoragik yaitu sebesar Rp 12.220.429 dan rata-rata biaya sakit atau cost of treatment yang terendah adalah transient ischemic attack (TIA) yaitu sebesar Rp 3.686.268. Sedangkan berdasarkan ICD-10, terdapat 4 kelompok diagnosis stroke. Dari keempat kelompok diagnosis tersebut, rata-rata biaya sakit tertinggi adalah CVA infarct due to embolism yaitu sebesar Rp 13.176.836 dan ratarata biaya sakit yang terendah adalah transient ischemic attack (TIA).

\section{Pembahasan \\ Direct Cost}

Direct cost pada penelitian ini diidentifikasi dari biaya rawat jalan dan biaya rawat inap. Biaya rawat jalan adalah biaya yang dikeluarkan oleh pasien untuk berkunjung ke fasilitas kesehatan tingkat pertama sebelum pasien dilarikan atau dirujuk ke fasilitas kesehatan rujukan tingkat lanjutan (FKRTL). Sebagian besar pasien yang melakukan kunjungan ini tidak dikenakan biaya atas kunjungan yang dilakukannya, akan tetapi tetap mengeluarkan biaya secara out of pocket (OOP) untuk kebutuhan transportasi.

Selain itu, terdapat biaya rawat inap yang harus dikeluarkan pasien yang terdiri dari seluruh biaya perawatan mulai dari pasien masuk instalasi rawat darurat (IRD) hingga pasien keluar dari rumah sakit serta biaya transportasi. Dari semua komponen biaya, kontribusi terbesar biaya rawat inap adalah biaya tindakan keperawatan. Semakin banyak jumlah tindakan yang dilakukan maka semakin besar pula biaya rawat inap yang dikeluarkan oleh pasien.

Pada penelitian ini terdapat kondisi tertentu pasien yang menyebabkan tindakan keperawatan yang dilakukan semakin banyak. Kondisi tersebut dapat terjadi ketika pasien mendapatkan tindakan pemasangan dan pelepasan infus yang dilakukan dua kali dalam sehari. Pergantian lokasi tusukan infus ini dapat dilakukan setiap 48-72 jam menggunakan set infus baru (Hidayat, 2008). Pergantian infus juga dapat terjadi jika pemasangan infus pertama dianggap gagal karena kondisi fisiologis pasien.

Hal yang sama juga terjadi pada tindakan pelepasan kateter. Terdapat tindakan pelepasan kateter yang tercatat dilakukan dua kali di hari yang sama saat pasien discharge dan terdapat pasien yang tercatat mendapatkan perawatan kateter namun tidak tercatat mendapatkan tindakan pemasangan kateter. Pencatatan tindakan keperawatan juga berpengaruh pada besar kecilnya biaya rawat inap. Oleh karena itu, diperlukan adanya tindakan keperawatan yang tepat dan pencatatan tindakan keperawatan yang baik sehingga dapat mempengaruhi peningkatan efektivitas biaya.

Selain biaya tindakan keperawatan, terdapat juga biaya farmasi yang memiliki pengaruh besar terhadap besarnya biaya rawat inap. Jumlah dan jenis kebutuhan farmasi yang kurang tepat dapat menurunkan efisiensi biaya rawat inap. Pada penelitian ini terdapat pasien yang tercatat menggunakan infusion set dengan jumlah lebih banyak dari tindakan pemasangan dan pelepasan infus yang diterimanya. Selain itu, juga terdapat pasien yang tercatat menggunakan selang oksigen dan respiratory humidifier namun pada tindakan keperawatan tidak tercatat aktivitas pemasangan oksigen. Hal yang demikian dapat menyebabkan inefisiensi biaya rawat inap.

Ketepatan pelayanan yang diberikan serta kesesuaian pencatatan sangat diperlukan untuk mengupayakan pengendalian biaya (cost containment). Pengendalian atau penekanan biaya dimaksudkan untuk mencapai cost effectiveness. Menurut Trisnawati dalam Vera (2012) pengendalian biaya dapat dilakukan 
melalui pengawasan berkelanjutan serta melakukan analisis terhadap penyimpangan yang terjadi sehingga dapat diketahui penyebab terjadinya penyimpangan tersebut kemudian ditindaklanjuti. Dengan demikian, maka diperlukan pengawasan terhadap tindakan pencatatan pelayanan yang diberikan kepada pasien melalui tindakan koreksi ulang sehingga dapat meminimalisir adanya penyimpangan.

\section{Indirect Cost}

Indirect cost diidentifikasi dari pendapatan yang hilang akibat sakit dari pasien, pendapatan yang hilang dari pendamping pasien dan biaya lainlain. Dari ketiga komponen biaya tersebut yang berkontribusi terbesar pada indirect cost adalah biaya lain-lain. Biaya lain-lain ini terdiri dari biaya transportasi pendamping, biaya makan dan minum pendamping pasien, dan biaya higiene personal pasien.

Biaya transportasi pendamping diartikan sebagai biaya yang dikeluarkan pendamping untuk keperluan transportasi selama menjadi pendamping pasien. Semakin banyak jumlah pendamping pasien, maka akan semakin besar pula biaya transportasi pendamping yang mungkin akan dikeluarkan. Sedangkan biaya makan dan minum pendamping adalah biaya yang dikeluarkan untuk keperluan makan dan minum pendamping selama mendampingi pasien. Untuk menekan biaya transportasi serta biaya makan dan minum pendamping, diperlukan kebijakan rumah sakit yang tegas berupa pembatasan jam kunjung maupun pembatasan jumlah pendamping pasien dengan cara pengadaan kartu pengunjung pasien.

Pembatasan jumlah pendamping dan pengunjung pasien ini juga dapat menekan indirect cost dari perspektif rumah sakit. Indirect cost dari perspektif rumah sakit ini sering disebut sebagai overhead cost. Biaya ini merupakan biaya penunjang pelayanan seperti biaya penggunaan listrik dan biaya penggunaan air.
Semakin banyak pengunjung dan pendamping pasien memungkinkan bertambah besar pula penggunaan air dan listrik di rumah sakit.

Secara garis besar hasil penelitian ini menunjukkan bahwa meskipun semua responden adalah peserta BPJS, namun mereka masih perlu mengeluarkan indirect cost secara out of pocket atau OOP. Seperti yang diketahui bahwa keberadaan asuransi kesehatan diharapkan dapat mengurangi risiko masyarakat menanggung biaya pelayanan medis dari kantong sendiri atau OOP, dalam jumlah yang sulit diprediksi dan kadang-kadang memerlukan biaya yang sangat besar. Pengeluaran biaya secara OOP ini dapat menjadi suatu beban ekonomi bagi masyarakat. Sehingga dengan demikian, indirect cost yang dikeluarkan secara OOP ini dapat dijadikan bahan pertimbangan dalam penetapan premi.

\section{Cost of Treatment}

Total biaya sakit atau cost of treatment diidentifikasi dari dua jenis biaya yaitu, biaya langsung (direct cost) dan indirect cost (indirect cost). Dari kedua komponen cost of treatment tersebut $87,7 \%$ diantaranya adalah direct cost dan sekitar 12,3\% diantaranya merupakan indirect cost. Berdasarkan klasifikasinya secara garis besar pasien stroke dibedakan menjadi 3 kelompok yaitu, stroke iskemik, stroke hemoragik, dan transient cerebral ischemic attack (TIA). Secara keseluruhan dapat diketahui bahwa penderita stroke pada kelompok klasifikasi TIA memiliki rata-rata cost of treatment yang lebih rendah dibandingkan dengan diagnosis yang lain. Hal ini dikarenakan TIA merupakan fase peringatan dini yang memungkinkan menjadi cikal bakal terjadinya infarct serebrum. Meski demikian, orang-orang dengan diagnosis TIA memerlukan pemeriksaan medis maupun neurologis serta perawatan medis yang tepat. Hal ini untuk mencegah terjadinya stroke yang lebih parah. 
Sementara itu, rata-rata cost of treatment yang tertinggi yakni pada kelompok stroke hemoragik. Hal ini sejalan dengan penelitian yang dilakukan oleh Damayanti yang menunjukkan bahwa biaya pada stroke hemoragik menunjukkan angka yang lebih tinggi daripada biaya stroke iskemik (Damayanti, 2010). Hasil penelitian Damayanti menunjukkan bahwa rata-rata biaya terapi total untuk stroke iskemik $\mathrm{Rp} 4.340 .000$ dan hemoragik $\mathrm{Rp}$ 5.300.000. Meski demikian, angka tersebut lebih kecil jika dibandingkan dengan biaya sakit stroke pada penelitian ini. Hal ini dikarenakan pada penelitian yang dilakukan oleh Damayanti tidak mengikutsertakan komponen indirect cost (indirect cost) pada perhitungan biaya sakit (cost of treatment).

Perhitungan cost of treatment pada penderita stroke ini dapat dianalisis lebih lanjut berdasarkan kelompok diagnosis yang merujuk pada ICD-10. Jika dikelompokkan berdasarkan klasifikasi diagnosis ICD-10 maka pada penelitian ini terdapat 4 kelompok diagnosis stroke yaitu, cerebral infarction (CVA infarct), CVA infarct due to embolism, intracerebral haemorrhage (ICH), dan transient cerebral ischemic attack (TIA). Dari keempat diagnosis tersebut, rata-rata biaya terendah adalah pada biaya penderita stroke dengan diagnosis transient cerebral ischemic attack (TIA). Selanjutnya untuk rata-rata cost of treatment tertinggi yaitu pada penderita stroke dengan diagnosis CVA infarct due to embolism.

Perhitungan biaya sakit berdasarkan ICD-10 ini dapat digunakan untuk analisis lebih lanjut mengenai tingkat efisiensi biaya pada masingmasing diagnosis. Sehingga pihak rumah sakit dapat menganalisis lebih lanjut kemungkinan penggunaan biaya yang kurang efisien dalam pelayanan stroke. Penggunaan biaya yang kurang efisien ini nantinya dapat menyebabkan kerugian bagi rumah sakit itu sendiri. Untuk itu diperlukan adanya upaya pengendalian biaya yang nantinya dapat melahirkan suatu kebijakan di lingkungan rumah sakit itu sendiri. Upaya pengendalian biaya ini dapat dilakukan dengan menelusuri masing-masing komponen biaya langsung rawat inap.

Pada era JKN ini, sistem pembiayaan dilakukan dengan sistem prospektif. Tujuan dari sistem pembayaran prospektif ini adalah untuk memotivasi penyedia layanan kesehatan, dalam hal ini rumah sakit untuk memberikan perawatan pasien secara efektif dan efisien (Rozany et al., 2017). Salah satu output kebijakan untuk pengendalian biaya di rumah sakit adalah pembuatan clinical pathway yang merupakan salah satu bentuk standar pada proses pelayanan.

RSUD dr. Mohamad Saleh Kota Probolinggo telah membuat clinical pathway sebagai bentuk kendali mutu pelayanan. Meski telah memiliki $\mathrm{CP}$, namun masih belum diimplementasikan dengan baik serta belum terdapat monitoring dan evaluasi terkait pelaksanaannya. Pada penelitian Nichol dalam Rozany et al., (2017) disebutkan bahwa dengan adanya clinical pathway maka mengurangi penggunaan sumber daya dan meningkatkan efisiensi pada pembiayaan. Maka diperlukan penerapan $\mathrm{CP}$ pada pelayanan stroke sebagai bentuk pengendalian mutu pelayanan yang dapat dilihat dari tingkat kesesuaian pelayanan yang diberikan dengan $\mathrm{CP}$ yang telah ditetapkan oleh rumah sakit.

\section{Kesimpulan dan Saran Kesimpulan}

Penelitian ini dilakukan pada 40 responden pasien penderita stroke di RSUD dr. Moh. Saleh yang sebagian besar responden berjenis kelamin perempuan serta memiliki usia pada kelompok umur lansia akhir, mayoritas memiliki tingkat pendidikan tamat $\mathrm{SD}$ / sederajat dan tidak bekerja. Pasien yang menjadi sampel telah mewakili 4 kelompok diagnosis berdasarkan ICD-10 yaitu, cerebral infarction, cva infarct due to embolism, 
intracerebral haemorrhage, dan transient cerebral ischemic attack.

Rata-rata direct cost penderita stroke peserta BPJS di RSUD dr. Moh. Saleh adalah Rp 8.278.584 dengan rentang nilai minimum dan maksimum sebesar Rp 2.024.179-Rp 22.534.479. Komponen terbesar direct cost adalah biaya rawat inap. Tindakan keperawatan merupakan komponen terbesar pada biaya rawat inap. Sedangkan rata-rata indirect cost (indirect cost) penderita stroke peserta BPJS di RSUD dr. Moh. Saleh adalah Rp 974.383 dengan rentan nilai minimum dan maksimum sebesar $\mathrm{Rp}$ 446.300-Rp 2.124.200. Komponen terbesar indirect cost adalah biaya lain-lain. Sehingga didapatkan rata-rata cost of treatment adalah $\mathrm{Rp}$ 9.252.967 dengan rentan nilai minimum hingga maksimum sebesar Rp 2.766.979-Rp 24.242.679 yang komponen terbesarnya adalah direct cost

\section{Saran}

RSUD dr. Mohamad Saleh Kota Probolinggo perlu meningkatkan kesesuaian pencatatan tindakan keperawatan dengan tindakan keperawatan yang dilakukan serta melakukan tindakan koreksi ulang terkait pencatatan tersebut, mengimplementasikan clinical pathway sebagai bentuk kendali mutu pelayanan serta melakukan monitoring dan evaluasi terhadap implementasinya, mempertegas pelaksanaan tata tertib terkait kunjungan pasien dengan cara pengadaan kartu identitas pengunjung, dan melakukan analisis perhitungan cost recovery rate atau tingkat pemulihan biaya stroke.

\section{Ucapan Terima Kasih}

Peneliti mengucapkan terima kasih kepada RSUD dr. Mohamad Saleh Kota Probolinggo yang berkenan bekerjasama dengan Fakultas Kesehatan Masyarakat Universitas Jember.

\section{Daftar Pustaka}

Badan Penyelenggara Jaminan Sosial. 2017. Pembiayaan Diagnostik PAK dan Pelayanan Penyakit Kronis Pasca Pensiun . Jakarta: BPJS.

Damayanti, T. 2010. Analisis Biaya Terapi Pasien Stroke Rawat Inap di RSUP Dr. SardjitoTahun 2007. Tesis. Program S2 Ilmu Farmasi Universitas Gadjah Mada. Yogyakarta.

Hidayat, A.A. 2008. Pengantar Kebutuhan Dasar Manusia: Aplikasi Konsep dan Proses Keperawatan. Jakarta: Salemba Medika.

Hudayani, M. 2016. Komparasi Biaya Riil dengan Tarif INA CBGs dan Analisis Komponen Biaya yang Berpengaruh pada Pasien Stroke Hemoragi Rawat Inap Peserta JKN di Rumah Sakit Kabupaten Pekalongan. Tesis. Program S2 Ilmu Farmasi Universitas Gadjah Mada. Yogyakarta.

Kementerian Kesehatan Republik Indonesia. 2013. Riset Kesehatan Dasar: Riskesdas 2013. Jakarta: Kemenkes RI.

Kementerian Kesehatan Republik Indonesia. 2014a. Info Datin Sistuasi Kesehatan Jantung. Jakarta: Kemenkes RI.

Kementerian Kesehatan Republik Indonesia. 2014b, Desember 11. Kebanyakan Peserta JKN Mandiri Miliki Penyakit Katastropik. Depkes.go.id. Dipetik dari: http://www.depkes.go.id/pdf.php?id=141222 00001.

Laksmiarti, T., T. Rachmawati, T. J. Angkasawati, M. S. Pramono, L. Kristiana, N. Izza, dan C.Latifah. 2013. Riset Kesehatan Dasar Dalam Angka Provinsi Jawa Timur (Riskesdas 2013). Jakarta: Lembaga Penelitian Badan Litbangkes.

Lund Research Ltd. 2012. Purposive Sampling. dissertation.laerd.com. Dipetik dari: http://dissertation.laerd.com/purposivesampling.php. 
Puspandari, D. A. 2015. Model Estimasi Biaya Obat Pasien Kanker Payudara dan Faktor Penentu di Rumah Sakit di Indonesia. Disertasi. Program Doktor Fakultas Kedokteran Universitas Gadjah Mada. Yogyakarta.

Rozany, F., N. Yuliansyah, dan S. J. Susilo. 2017. Panduan Praktek Klinis dan Clinical Pathway Sebagai Solusi Efisiensi Pembiayaan Diagnosa Hernia Inguinalis, Appendisitis, dan Sectio Caesarea di RSI Gondanglegi. Jurnal Medicoeticolegal dan Manajemen Rumah Sakit, Vol 6(2): hal. 122-129.

Sugiyono. 2015. Metode Penelitian Kuantitatif, Kualitatif, dan $R \& D$. Bandung: Alfabeta Cv.

Undang-Undang Republik Indonesia Nomor 40 Tahun 2004 Sistem Jaminan Sosial Nasional. 19 Oktober 2004. Lembaran Negara Republik Indonesia Tahun 2004 Nomor 150. Jakarta.

Veria, N. A. B. 2012. Persepsi Pegawai Terhadap Upaya Cost Containment di Instalasi Farmasi RSUD Pasar Rebo Tahun 2011. Tesis. Program S2 Fakultas Kesehatan Masyarakat Universitas Indonesia. Depok. 